\title{
MIGRATORY MOVEMENT: THE POLITICS OF ETHNIC COMMUNITY (RE) CONSTRUCTION AMONG CREOLES OF COLOR, 1920-1940
}

\author{
Andrew Jolivétte \\ San Francisco State University
}

\section{INTRODUCTION}

This article considers the social and economic conditions under which Creoles of Color left the state of Louisiana from 1920-1940. ${ }^{1}$ Because Creoles in the years following 1920 were legally reclassified as black, many lost their land, social and legal rights, and access to education as well as the possibility of upward mobility to which they had previously had access when they were accorded the status of a distinct/legal ethnic group. Creole families had to make decisions about the economic, social, religious, and cultural futures of their children and the community as a whole. As a form of resistance to colonial and neocolonial rule, thousands of Creoles left Louisiana, following the pattern established by members of the previous generation who had anticipated the advent and implications of the new legal racial system as far back as the mid to late 1800s and had engaged in the first wave of migration from 1840-1890, moving primarily from rural ethnic enclaves to larger urban cities within the US and to international sites such as Mexico, Cuba, Haiti, Brazil, and other parts of the 
Caribbean and Latin America where racial lines were more fluid (Gehman, 1994).

This essay addresses the second wave of Creole migration which begins around 1920 and ends in the 1950s. I will focus primarily on the twenty-year span from 1920-1940, demonstrating that a detailed analysis of the material and cultural conditions in Louisiana during this period is essential to understanding how reconstruction, Act 220, and segregation led to Creole migration and community reconstruction in the form of ethnic enclaves. Also essential to an understanding of these phenomena is a critical evaluation of the ideology behind "passing," which reveals an underlying political, racial, and economic project that both denies white and black racism and results in the marginalization of mixed race, hybrid, mestizo populations. Consequently, I will devote considerable attention in this article to a critical discussion of acts historically considered as ethnic "performativity" and ethnic "authenticity." Finally, I will examine the meaning of home for Creoles living within the diaspora both in and out of Louisiana, and explore how the travel between Creole enclaves outside of and within Louisiana, along with the economic support provided by migrating Creoles to family members that remained, mirrors the patterns of transnational and diasporic communities globally.

\section{ECONOMIC, POLITICAL AND RACIAL PUSH FACTORS}

The 1920s brought about an economic decline in Louisiana that sent the state literally spiraling into abject poverty. The ramifications of the post-slave economy and Jim Crow segregation were heaviest on Creoles of Color, because they stood to lose the most as a result of the change in their racial status from Creole to Black. Because of the drastic changes under reconstruction, political power-in the form of voting-was not exercised in the way that it once had been by the Creole of Color community. As anticipated, registrationparticularly among blacks-declined precipitously. The number of whites on the rolls statewide dropped from 164,088 to 91,716 in 1904; black registration simply collapsed, falling from 130,344 to 1,342 . Although the number of white voters slowly climbed as the state population increased, and especially after women began to register under the Nineteenth Amendment (ratified in 
1920), black registration in Louisiana, as elsewhere, shriveled even further. Only 735 Louisiana blacks were listed on the rolls in 1918, at the same time there were 144,832 registered whites, still below the 1896 level. Black registration fell to its lowest point in the twentieth century in 1922, when exactly 598 black voters were listed in Louisiana compared with 191,789 whites, including women. As late as 1940 only 886 Negroes were registered (Wall, 1984: 235).

The socially engineered decline in voting and voter registration among blacks is one way in which the African American community has historically been disenfranchised. Creoles, who became a part of this category in 1920, were faced with the realization that, to continue to make a life as they had known it, they would have to leave Louisiana. This was true even during a brief period in the early 1920s when the newly-emerging oil industry began to boost the suffering Louisiana economy, since opportunities for work were given on a priority basis to whites; in any case, this brief period of economic prosperity in the state was short lived and worsened at the end of World War I.

By 1920 a modern petrochemical industry was rapidly developing in Louisiana, with Baton Rouge, Monroe, Shreveport, and Lake Charles its centers. Abundant supplies of fossil fuels stimulated expansion of utilities, pipelines, railroads, and water transportation. This economic upturn created thousands of new jobs, not only in the new industries themselves, but in construction, service occupations, retail sales, and state and local government. Rural Louisiana nurtured the coming political revolution. The artificial markets created by World War I sparked a cotton boom that sent prices up to 36 cents per pound by 1918. But the postwar depression knocked prices down again, and by the 1920s, Louisiana's farmers were again impoverished, in debt, and in a rebellious mood (Wall, 1984: 239-240).

One parish in particular was hit by the disparity of life in the 1930s and 40s. Frilot Cove has always been isolated and self-contained. Most people owned their land and supported themselves with farming. However, from the late 1930s to the early 1950s, numerous residents left farming for more lucrative jobs in northern cities like, Detroit and Rochester, NY. Many of 
these same emigrants returned home to Frilot Cove when they retired (Billeaudeau, 1998:20 from the Creole Center Archive Records).

Although many scholars in the twentieth century observe that Creoles maintained much of their distinct culture, others have only analyzed this in the context of black-white relations and have reduced the Creole experience as multiracial to an issue of "passing" for white or being "authentically" black. The presumption that Creoles who are white in ancestry (in many cases more white than black and more Native American than either) are 'passing' for White seems a curious position, when culturally and socially speaking the same could be said of Creoles who pose as 'authentic' members of the Black community, when culturally and ancestrally it could be argued that some members of this population are historically less related to blacks than they are to whites and Indians.

The lack of power came hard to a population that prided itself on its accomplishments: owning property, paying taxes, and working hard to move through the higher educational system. These ethical considerations are still reinforced by the Creole family, their church and community to this day. According to local Louisiana Creole activist and scholar, Terrel Delphin, "denial of black status, that is to say "powerlessness", (as constructed by the ideology of white supremacy) was a necessity to maintain Creole identity. Acknowledging it has been necessary too, and in spite of the fact that historically many, if not most, Creoles could have left their region and drifted into the mainstream as whites, most chose to stay together even in distant places."

We left Louisiana in groups. First my uncles came out West in the late 40 s and early 50 s and then my dad and finally we came with my mama on the train. We could have passed for white and some of us did, but not me, not my brother and my other sister. Maybe it's cuz' we're the oldest, and the oldest can remember. I remember what it was like to not be black, to not be white, and to not be able to really talk about being Indian. People didn't know what Creoles was...so I had to tell them. We spoke 
Creole at home. We ate Creole food. I think we were a mixed family, lots of culture, lots of Creole traditions like on Christmas and Easter...and I passed some of these things to my kids (Creole Interview Respondent).

Creoles have traditionally taken care of one another; kinship ties offered a tool for that, brokering jobs and security for those who left Cane River. Attitudes about Cane River, almost nostalgic on the part of the first generation to leave, tend to draw them back. Many left in the 1930-1960 period, but virtually all of them kept their connections. Most moved to cities: Chicago, Los Angeles, Houston, New Orleans. Rural life experiences rapidly turned into nostalgia (Delphin, 1995: 15). These Creoles formed bonds in new places because they had ties to other Creoles who had already migrated and established a community network among other Creoles.

\section{COMMUNITY PRESERVATION AND RECONSTRUCTION THROUGH RITUAL}

One Los Angeles lady I interviewed recalled, "My daddy thought Louisiana was heaven. He talked to us about it all the time." Whatever the motivation, people came home. "Christmas, Easter, other feast days, not to mention funerals, weddings, birthdays and the Fourth of July- almost any excuse set people visiting." The Church Fair in October and the Fourth of July rounded out secular holidays. The Fourth of July correlated with the old Fete du Ble or corn fest, a first fruits ceremonial time celebrated by Native Americans in Louisiana. Whatever the origin, it was a good time to visit. Travel from Isle Brevelle to Chicago, or even Los Angeles, was commonplace. Isolation was certainly not geographic. By the 1950s, frequent cross-country trips were common, and they remain so today (Delphin, 1995: 15).

Reunions and la-la's or dances were the ways that we got to see our people who were from back home. But so see here in the North...we saw family at church, at school, and at socials. You knew who was Creole just by the name or the look and sometimes you'd meet a cousin (cou-saan). 
Visiting is something we often did. Sundays after church were a great time for visiting. There'd be food, gossip, and plans for birthdays and holidays. We'd get to talk about how people back home were doing and could send them things if they needed. In the 60's, I think '67 or '68 we went back to bury my na-nan. It was special because we felt like we had never left. I'll go back someday. I wanna be buried there too, its home for me (Creole Interview Respondent).

This travel back and forth between the Creole homeland and various locations within the Creole diaspora not only indicates a pattern of revolving migration and national travel, but also reveals the distinct ethnic identity maintained by Creole communities that continues to be tied to Louisiana and the ethnic specificity of being multiracial. Creoles could have easily blended into multiple ethnic communities across the United States as many did do during the first wave of migration to Mexico in the nineteenth century, but most, it seems, chose to be true to their ethnic and cultural distinctiveness, by not denying any portion of their ancestry.

Sister Frances Jerome Woods (1972) noted the tendency of Creoles to settle together mostly in northern cities close to Catholic Churches and in some southern cities, but especially in Houston. She attributed that to the fact that they had an easier time in Houston where they blended with Mexicans and other dark-skinned people. Creoles amicably explain such settlement patterns by the fact that they went to places where they had relatives, people to help them, to broker jobs and resources (Delphin, 1995: 15). As a result of the marginalization faced by Creoles after the implementation of new laws that prohibited them from having their own ethnic category, Creoles made the decision to reconstruct and reconfigure Creole communities across the United States in the image of the homes they knew in Louisiana.

Many Creole families migrated from Louisiana to California in the 1940s lured by work, including, the Ravare, Landry, Francis, Patin, Bordenave, Ganier, Laurent, Metoyer, King, Beridon, and Fredericks families. Many of these consisted of master brick masons. Once in California they continued to form colonies as in Louisiana and worked and played together. The art and expertise 
continued to be passed from generation to generation as was done before the Civil War and after the $20^{\text {th }}$ century migration (Ravare, 1998: 24, Creole Center Archive Records).

The evolution of new Creole enclaves in the 1920-1940 period suggests a form of cultural articulation and agency that can only be manifested through a deconstruction of a priori conclusions about the stability, and fixed, closed categories of group identity. Scholars of the Creole community have tended to produce this effect in their overemphasis on the Creole perspective from a New Orleans hegemonic perspective, ignoring the differences in the Creole population in urban versus rural spaces. The project of radical contextualisation is straightforward and arcane. Many of the old binaries are subverted because neither abstraction nor empiricism (in knowledge production), neither theory nor practice (in political action), neither universalism nor relativism (in aesthetic judgments), can resolve any of Kant's three foundational questions of philosophy: what do I know, what should I do, what do I want. The answers to these questions depend upon abolishing the a priori and determining the grounds on which they are made, accepting that the traces of historicity and spatiality are always a constitutive feature of the processes of the subject and object formation (Keith, 2000: 532). Creole communities successfully produced ethnic enclaves that speak to the philosophical questions raised by Kant. Creole were Creole because of what they did and not simply because of what people told them they were.

My parents were from the Lake Charles area. They both went to Xavier University. They knew their Creole culture. They studied it. They grew-up on it... in the fields, at the family gatherings. They told me stories about how Creole people came to be and said that we kids should never be ashamed of who we are and that being Creole isn't about denying who we are, it's about embracing and celebrating our many faces and colors. "Society will tell you otherwise" my papa use to say, "but young lady keep your head up, look them in the eye, and tell them who you are, tell them you and your kin are Creole people" (Creole Interview Respondent). 


\section{SUBVERTING THE RACIAL BINARY OF BLACK -WHITE PERFORMATIVITY}

As Creoles moved toward this space of ambiguity and cultural continuity, their representation to the external world of whites and blacks (especially in Louisiana) caused ruptures in the binary thinking that was established from 1865-1920. One interviewee commented on the ramifications of this period.

But what we have to do as a people whether its Creole, Black, Indian, is stick together...we're all the same. I use to have to run home after school during those times. I wasn't running with the White folks, but I couldn't be with the Black folks because they wouldn't accept me. Because I was too light. I had to fend for myself more or less until like I said, I went to high school. Cuz' I remember this girl who lived across the street in the Valencia Gardens named Ana, she use to run me with a rug knife (Creole Interview Respondent).

The aftermath of this period has led to the "shaming" of Creoles who refuse to pass for black only or white only, for a third space ethnic identity which is inclusive not only of white and black, but of Indian as well (see figure 1.1). To this day anyone who has a trace of African blood in their ancestry is considered adamantly-forced by both the white and African American population in general-to be Black. Any deviance from the total acceptance of Blackness and/or any outward identification with and/or highlighting of the French or Indian part of our racial composition is widely frowned upon by both African Americans and Whites (Sarpy, 2001: 58). 


\section{Figure 1.1}

\section{Creole Migration Ethnic Identity Options}

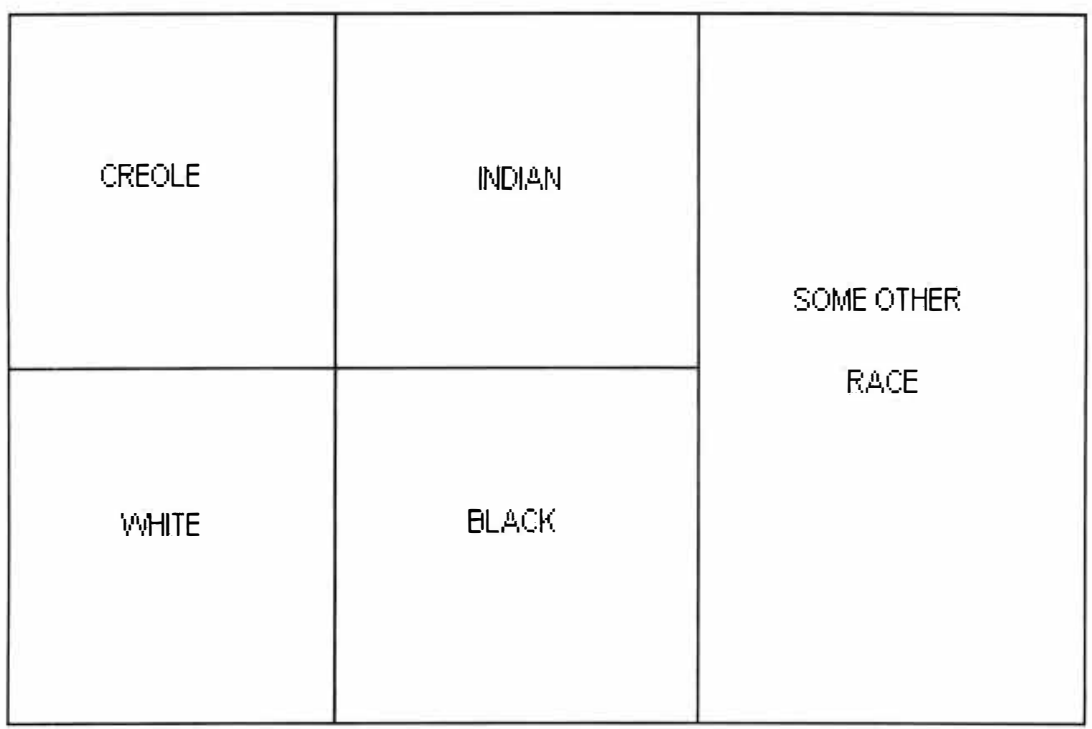

"Again, it was important for many to be Creole as opposed to exclusively white, Mexican, Negro, or Native American-any of the groups which could have, and occasionally did, accept them as individuals. Rather than to "passer," the Creoles tended to perpetuate and maintain their group identity wherever they went" (Delphin, 1995:16 Creole Center Archive Records). Creoles living within these new urban locations scattered nationally throughout the United States and worked to embrace all of the components of their ethnic and cultural make-up, but as is evidenced by the lack of scholarship on the Native American contributions to the development of contemporary Creole culture, one could deduce the conclusion that this aspect of the culture was denied and erased through calculated, legal, economic, and sexed/gendered practices. Consider the following respondent's comments about historical inaccuracy:

There's a lot of races in those swamps there. I'm sure he was blind to it. But they were never interviewed. There was a linguist, who was married to Mary Haas. 
He was working on the Chitimacha and she was working on the Tunica and they found a Black man who spoke Chitimacha, what I hate is he probably also spoke Mobilian, but they didn't know that, but he did become one of their Chitimacha informants. But he's one of the few people who they talked to about Blacks and Indians. Nobody much talked to Mexican/mixed people (French/Indian Interview Respondent).

These historic moves of erasure cause a slippage between the reality of lived experience and ethnic identification as a socially ascribed status. The assertion for example, that tribes such as the Atakapa in southwest Louisiana are "completely" extinct, speak to the erasure of this group's ability and of Indian identity in general, to continue to exist in mixed race communities, such as that of the Creole.

These descendants of the Atakapa suffered great neglect, along with other minorities, through all of the prior two centuries and the first half of the $20^{\text {th }}$ century. They were denied their racial identity. And they were denied civil rights and adequate schooling, along with African Americans according to anthropologist and linguist, Hubert Singleton.

The Indian children were denied completely the remnant knowledge of their people's history, culture, and language. Even at Lake Charles, where the Smithsonian had preserved these "Creole" people's Native American language and had pleaded that the language be studied and appreciated, local authorities appear not even once to have offered its study to these Atakapa descendants. The author himself attended a Lake Charles public school in the 1930s with scores of children who, like him, were "Creoles" of Atakapa ancestry. Never once was he told by the school about his people's own language, history, and culture. Simply they were never mentioned (Singleton, 1999:58, Creole Center Archive Records). 
The aspects of the culture that are however, indigenous to some degree have continued to be practiced by Creoles all across the Diaspora. The issue however, is to what degree do these Creoles know which aspects of the culture are Native American and which are not. As with all American Indian communities, issues of the loss of language speakers in younger generations and cultural patterns of life are changing and sometimes blended with mainstream culture to form a cultural hybrid. The loss of power after the passage of Act $220^{2}$ left many Creoles searching for ways to resist and reform laws. Several legal cases disputed laws that segregated Creoles from the white populations and caused Creoles to live in greater numbers among the African American communities of Louisiana.

Hubert Singleton, a retired anthropologist and linguist who now resides in Hammond, Louisiana conducted a study of the Atakapa people and language that reveals many connections to the Creole people that would indicate that they are indeed the same people, but in a hybrid form. Southwest Louisiana and southeast Texas' pretense that the Atakapa language and people were extinct had a very damaging result in both states "As a result of both states' past and present policy of denying a people's very existence by every means possible, even by encouraging the use among them of name tags, now of clouded meaning, that really do not convey their Indian ancestry, thousands of so-called "Creoles", "Creoles of Color", and former "Coloreds" in and from southwest Louisiana and southeast Texas live confused about, and even ignorant of, their Indian heritage" (Singleton, 1999:58).

In the entire description of Creoles in the book entitled, Creoles of Color in the Bayou Country not once are the people directly described by the actual word "Indian" or "Atakapa", proper for many of them. This is what happens when a people's language goes extinct. Everybody, including many of the people themselves, lose sight of who they really are according to Singleton. However, they are indirectly or virtually described as Indians when that book relates Creoles of Color to customs and traits historically unique to Atakapas: the practice of healing, the dancing of Zydeco that from pre-history was the Atakapas' good-time dance, long association with Catholicism, clannishness, long history of dwelling on the 
southwest prairies, a wide range of complexions, etc. (Singleton, 1999:58 Creole Center Archive Records).

The examples articulated by Singleton reveal important aspects of Creole culture that are influenced by one of their major American Indian ancestral groups, the Atakapa. Moreover, these traditions have been the fabric of some of the cultural practices that held Creole communities together during the second migration wave from 1920-1940. In urban spaces, the Zydeco dance and the Church have been staple forms of cultural persistence among Creoles. The have worked to preserve life as it was in Louisiana and in the process have imported, transplanted, and shared their rich cultural traditions with surrounding non-Creole communities. Catholicism, Zydeco music, and Creole cooking are the most known about aspects of Creole culture globally, because they have been regenerated by Creole enclaves throughout the United States and internationally.

Creoles are starting to be everywhere. On Oprah that author was there talking about her people from Cane River and the Creoles. Every summer kind of like the Indian Pow wow circuit there is a Zydeco dance and musical festival circuit throughout southern California, eastern Texas, Louisiana and many other states. Then you got Emeril who always cooks the good Creole food. But what folks don't know is the origins of these foods and dances and even the language. Some argue about the French and Spanish or white origin and others focus on the African with an after word usually about the Indians. The food, aspects of the dance, music and language are from the Indian and the merging with the others. Our one pot dishes and our soup and corn and vegetable dishes all come from the Indians in the area some Choctaws and Chickasaws in my family (Creole Interview Respondent).

The movement and travel of Creole culture has been possible because of the un-relinquishing efforts of Creole families, especially, Creole women, to subvert society's binary categorization of Creoles 
as black or white, instead of both and more. The "more" that I speak of, is the seldom studied aspects of Native American culture. Creoles like other mixed-race American Indians experienced a form of ethnic renewal during the mid to late twentieth century, in part this renewal was because of a long standing history in which both Creole and Indian (and Indian as a part of Creole identity) ethnicity were made invisible.

\section{RETENTION OF NATIVE CULTURAL PATTERNS WITHIN CREOLE ETHNIC ENCLAVES}

The descendants of these populations have worked to maintain these classifications, but in the case of the Creole, it has remained especially important to not limit the identity to one aspect, even though evidence suggests a stronger American Indian and French presence than an African one. "Native American identity was the other alternative. In the first generation, some of the Metoyer family was descended from a Cannechi woman, an old-eighteenth century term for Apache slaves in Louisiana, and a part-white, part-black father" according to St. Augustine Society Founder, Terrel Delphin. Still other families are easily traced to Caddo, Choctaw and Lipan roots. He goes to say, "So, in terms of race, they were more genetically Native American than either white or black. Consequently, Native American connections can be made for virtually every family. Still, most prefer identity as Creole... Like white (French or Spanish), black, Native American or Indian mixtures are easily acknowledged, but only as a part of the mixCreole" (Delphin, 1995: 16).

As we have seen, Creoles have not only moved from their original homelands in the prairie parishes of southwest and western Louisiana for a better economic life, but have continued to preserve elements of all races, especially American Indian, in the maintenance of ethnic enclaves throughout the diasporic regions they inhabited during the 1920-1940 period. In the following section I will look at the ways in which notions of authenticity and performativity were played out once these Creole migrants reconstructed their communities in other cities. 


\section{PASSING, AUTHENTICITY, AND THE ARTICULATION OF THE POLITICS OF "PERFORMATIVITY"}

It is important to think about the complexities of social action, movement, and interrelationships that exist between social, personal, and cultural axes of group identity. Throughout the twentieth century, sociologists have observed an interdependent relationship between personal and societal influences in the making of individual identity, especially as it relates to one's ethnic identity. For Creoles of Color, the 1920-1940 period, represents an era of shifting meanings for Creoles because they had reached a point where many could no longer thrive economically or culturally in Louisiana. The passage of segregation and anti-miscegenation laws continued to have severe effects on this population, so they began to leave the state of Louisiana in larger numbers than ever before, because of the ways in which they saw their own identities being tied to both social and cultural systems of control that would not allow them to continue to live as they had for nearly two centuries. The problems of identity for this generation did not go away easily however. As Creoles have been located within the Black community so too have they had to deal with similar social problems and discrimination. Consider the following school-age experience as re-told by a Creole:

Like at Everett I remember at the end of the school year they would have a thing called like "Grey Neck Day" that's where all of the Black folks would beat up on all the white folks (or the light skinned folks) and its still happening today, where society pits a light skinned Black person against a dark skinned Black person and vice-versa. You know and it's sad. I use to have to runaway, so I wouldn't get beat up. It was hard to be Creole at school, but it was always easy at home because we ate and spoke Creole culture (Creole Interview Respondent).

Noted sociologist, Talcott Parsons' work in the area of social action is important in (re) thinking and (re) articulating the experience of Creole migrants as they transitioned into new regional areas and retained identities and communities that were similar even with different physical environments. In part, I would 
assert that Creole migrants were able to maintain Creole identities and practices, because the social and cultural systems under which they lived during the 1920s, 30s and 40s closely mirrored those same systems in Louisiana. As mixed race people they were able to seek out other mixed-race Creoles who whether family or friends would help them because they had being Creole in common. This type of kinship network as mixed-race people has not been talked about in recent scholarship.

According to Parsons, actors internalize meaningful order (a cultural system) that is more general than the set of social interactions (the social system) of which they are a part. This analytical argument means, on the one hand, that every social act specifies some broader cultural pattern; social action cannot be viewed mechanistically, for it inevitably has some cultural reference. On the other hand, because in analytical terms actions are also part of the social, not only the cultural system, the idealist perspective is also rejected. On the social system level, independent necessities are conceived of as coming into play, concerns about scarcity and allocation that cannot be deduced from patterns of meaning in and of themselves (Alexander, 1990:4). Thus for Creoles, social interaction and cultural systems of the meaning equally constitute the development and sustainability of their communities throughout the United States.

Because Parsons also posits the existence of a third analytical system-the personality-he can argue, moreover, that neither culture coding nor social determinism prohibits a role for the psychological imperatives. Action is symbolic, social, and motivational at the same time (Alexander, 1990:4). Creoles moving to northern U.S. states such as Michigan, New York, California, Missouri and Illinois reflect in their actions the sentiments of Parsons' theory of social action. The choice of choosing an ethnic identity as Creole and the notion of "performing" or "pretending" to be "white" as they moved to new locations can be seen as an example of the symbolic, social, and motivational all at once. Moreover, the actions of many were to retain a specifically Creole identity, while for others they decided to "become" Black and to a lesser extent, a great many lived as "Indians". My argument here is not to say that Creoles cannot live their lives as anyone of these ethnic groups 
solely, rather it is to say that one must analyze the influences of social interaction on the choices that these various individuals and communities made and continue to make.

Creoles therefore, exercise a certain ability to observe and retain a specific type of knowledge that separates their culture from that of other ethnic groups in the United States. Knowledge among individuals and groups about definitions of ethnic identity are therefore created and maintained by several sociological factorsindividuals, institutions, society, and self. Ethnic identity is, then, a dialectic between internal identification and external ascription. It is a socially negotiated and socially constructed status that varies as the audiences permitting particular ethnic options change. As individuals (or groups) moves through daily life, ethnic identities shifted in and out of prominence depending on the situation. Extending this image, the individual(s) or group(s) can be seen to carry a portfolio of ethnic identities that can be selected among, depending on the restrictions imposed by various social settings and constituencies. The result is an array or layering of ethnicities, with different identities activated at different times. This variable, negotiated view of ethnicity, typifies the constructionist model (Nagel, 1996: 21).

Creoles have historically been seen as "performing" race when in actuality a constructionist model or even a social interactionist view demonstrates that Creoles have been forced by their surroundings to shift from a collective group identity as Creole, to individual identifications with French, Indian, Spanish or African ancestry. Larger structural state apparatus models have compelled Creole migrants to deny the complexity of their ethnic and cultural distinctiveness by not offering a Creole category on any census forms. According to one respondent, anthropology has had a tremendous effect on the study of mixed-race Indian identity in Louisiana throughout the twentieth-century.

Part of it is the anthropologists' sort of colonialism that spawned anthropology in the first place. It's where you're always looking for the pristine people... people who have their culture. It's the old Boazian thing about finding a whole culture intact. See [John] Swanton wasn't interested in mixed families at all. He 
was looking for "real" Indians. Like there's a letter, you might run across it, he went below Azeel (sic) and he said, "I heard there were some Indians there and I went...but when I got there, there were just a bunch of Choctaws mixed with Black." (French/ Indian Interview Respondent).

Cultural formation therefore, as opposed to racial formation tends to more specifically and practically link the in-between spaces that inter-lock ethnic identification with not only ancestry and not only patterns of behavior and ritual, but connects both in a complex, fluid, and hybrid formation. Creoles as a mixed-race population subverted in the 1920s, 30s and 40s the notion that any black admixture, meant a completely black cultural identity. Although Creoles that migrated may have been legally defined as Black, their cultural and by extension, ethnic possibilities were multiple through the perpetuation of Creole culture. Culture is the sphere devoted specifically to the production, circulation, and use of meanings. The cultural sphere may in turn be broken down into sub-spheres: art, music, theater, fashion, literature, religion, media, and education (Sewell, 1999).

The study of culture, if culture is defined in this way, is the study of the activities that take place within these institutionally defined spheres and of the meanings produced in them (Sewell, 1999). Creoles rather than "pass" for any other ethnic group, often chose to preserve their new ethnic enclave communities, by reconstructing them through religion and church related rituals. These reconstructions were made possible, not by assuming a "purely authentic" Creole tradition that was "exactly" as it was in Louisiana, but rather it came through the increased migration of new Creole families to areas that had been established by earlier immigrants. Many following immigrant patterns of those who migrated internationally, have sent money so that other Creoles could move during years of deep depression, they also maintained dual households in new states that they moved to as well as in their local parishes. Many who left in the 20s, 30s, and 40s, returned in the $60 \mathrm{~s}, 70 \mathrm{~s}$, and $80 \mathrm{~s}$ to retire and to return to what they "knew as home". 
Together, Freddie and Alma built a new home and life in Los Angeles where they raised their seven children; Carol, Gary, Fred, Jr., Terry, Jacquelyn, Daryl and Rosalind. He worked two jobs most of his life to support and educate his family. Also, he supported the transition of the remainder of the family from Opelousas to Los Angeles. Freddie was an active member of St. John the Evangelist Church. He held several positions in the church to [that] include usher and the Knights of Peter Claver and most recently the administrator of the church hall (Metoyer, Bayou Talk Newspaper, Vol. 15 No.3, 2001 Creole Center Archive Records).

Creoles, like the man described in Bayou Talk (a national Creole news publication) explain the ways that the community of migrants continued to develop as distinct people despite living away from their homeland. These individuals and collective communities refused to think of race as a "pure essence" as an "authentic" form that places biological considerations above cultural realities. Having limited options, Creoles often did 'pass', sometimes because the new community they moved to saw them as white or black only, and in the case of others-like some members of my extended family-they saw it as an economic opportunity and as a true aspect of their identity and that it was their "right" to choose.

\section{CONCLUSION}

Cynthia Nakashima (1992) in an article on the denial on mixed race people asserts that the pressure to choose an ethnic identity by non-mixed race communities is what often forced people to become one race versus another. In this sense, I would argue that Creoles during the 1920-1940 period who "passed" for white, were really forced to do that, and that those who in my mind were also "passing" for black, were forced to do that too, when in Louisiana-they might have kept a Creole identity by isolating themselves from mainstream society. Some of these new enclaves, did isolate themselves, but this separation could not cut-off all interaction 
between Creoles and non-Creoles. Therefore, while some migrants maintained their identity as Creole, others clearly transformed their individual, familial, and group ethnic designation.

I don't know about everybody in my family. I knew that I was Creole. And Creoles is Black people, Red People, and White people. But what I remember is that when I was in junior high school...and in high school it was different. I could more or less...I knew. I've had people ask me to this day what nationality I am. Like when I was going to junior high school the White folks had it more or less cut and dry, dark against light, light against dark, so I was light, so I was put in with the so-called "White category" and when I went to high school I had to stand up and let them know what was what and you know I had a few fights and this and that, but I had to let them know (Creole Interview Respondent).

So, in order to have a racial and ethnic group with which to belong, multiracial people have been pressured to "choose," on an individual level, which of their groups to belong to. The direction to "check one box only" extends far beyond the census form to just about every aspect of life. In many cases the "choice" is made for the person by society, based on his or her physical appearance. However, often a person does not coincide culturally with the monoracial group with which he or she has been placed based on appearance; his or her cultural experience may have been that of a person intimately exposed to multiple racial and ethnic groups and cultures. For those multiracial people whose physical appearance leaves them racially ambiguous, questions about which group they identify with put them under constant pressure, especially when they feel that whoever is asking the question is looking for a particular answer (Nakashima, 1992:176). The notion of "passing" rarely takes into consideration the idea that an individual can have more than one ethnic identity. Racial formation theory, for example, does not go far enough in explicating the underlying racism and classism at work in the transformation of multiracial identities into monoracial ones. 
For Creoles like the respondent above, the peer-pressure to conform to an unrealistic expectation by both Whites and Blacks, is re-interpreted as a mandate to become more extreme and convincing in one's allegiance to one racial group, despite, admitted, physical, cultural, linguistic, and social differences. Actually, the famous old story of "passing" that has so interested both White and Black writers is really just one version of the phenomenon of choosing. "The ideology implicit in passing is hypodescent-that even if the person is genetically part White and looks physically White, as long as he or she has "one drop of Black blood," he or she is Black. In reality, if the character who had passed as White had instead chosen to live in the Black community as a Black person, this would just be another version of passing" (Nakashima, 1996).

A complex combination of cultural, ancestral, societal, symbolic, and individual personality factors give rise to the shift in Creole racial and ethnic meanings during the first half of the twentieth century. These new meanings represent an important historical moment in the transformation and development of the Creole people. The character of the Creoles as a community was deeply and profoundly influenced by the social interactions between their communities nationally and African American communities. Many Creoles outside of Louisiana moved to cities where there were large African American populations from the south. In some cases, strong cultural connections were made between the groups, while in others, inter-group relations were characterized by a distinct, continuing cultural and social separation. In fact, Creoles have faced resentment and displacement from both whites and blacks, and because of late $19^{\text {th }}$ and early $20^{\text {th }}$ century policies, have largely lost specific ancestral ties to their American Indian roots (although as we have seen they do still maintain some important cultural elements of Indian cultures from the southwest and northwest regions of Louisiana).

There is this kind of thing that in the 30's, 40's, 50 's, and even 60's to some extent, there was this tendency to shun people in the tribes. People who mixed left-they didn't go far, but they left. And they ceased to interact with "more" tribalized people. For 
example with the Tunica, some married Blacks and just moved off tribal land; they'd come back and visit with their families and stuff. They kind of broke family ties in some cases. Sometimes, like in one case I know, where a [Indian] gentleman married a Black lady, when she died, he went back to tribal land, but his children, who were half-Black never did. And when federal recognition passed, they did enroll, and so they were very active in the tribe later on. In the Creole communities of southwest Louisiana there were always Choctaws living and inter-married with Creoles. (French/Indian Interview Respondent).

Creoles during the 1920-1940 period lived in a somewhat paradoxical world because they could not truly be accepted by blacks or whites as Creole, or as "real authentic blacks", and certainly not as "whites" or "Indians". The process of creating new ethnic enclaves within the United States, however, indicates that despite external societal problems of labeling and classifying Creoles racially from 1920 to the present, Creoles themselves kept-even if privately among only other Creoles-this distinct cultural tradition that began in the eighteenth century. Evidence of this paradox, and the ambivalence of the response thereto, may be found in several forms, all of them elusive but suggestive. Demographic settlement patterns suggest a continuation of Creole determination to remain a distinctive multi-ethnic community. The process of "enclavement," a term suggested by sociologist Sr. Frances Jerome Woods, a specialist in Creole social organization, persisted over the decades of the late nineteenth and early twentieth centuries (Woods 1989:5). Distinctive Creole communities with fairly clear boundaries, recognized by members of the group as well as by outsiders, managed to maintain their existence over time. Endogamy also continued to reinforce the enclavement process by providing family networks on the basis of community formation and maintenance (Dormon, 1996:170).

Limited in their options during the years of 1920-1940, Creoles of Color fled Louisiana in the face of an emerging crisis that was both 
economic and cultural. The legal loss of their distinct ethnic status led to an acceleration in the loss of their distinct cultural status; rather than give this up, many migrated to other larger urban cities where they could prosper economically and where they could maintain a high level of connection to their Creole heritage by participating in cultural (rather than "racial") rituals and behaviors associated with Catholicism, Zydeco, specific labor skills, and a commitment to higher education for their children. Creole social interaction and community re-construction from 1920-1940 as we have seen could not have been possible without individual and collective resistance to an un-relenting Americanization process. While the legal system has classified Creoles as mono-racial, individuals, groups and organizations still living in many of these mixed race ethnic enclaves are battling to have their own category on the U.S. census. The variable of mixed-race in Creole migration was key to the safe travel and expansion of Creole heritage as inclusive of African, European, and Indian cultures.

This essay has revealed the ways in which Creole families taught their children at every opportunity to preserve their unique identity. Language, religion, and social gatherings were important variables in the formation of these new hybrid communities. The study of Creole migration and community (re)construction may prove useful in understanding the migration patterns of new emigrants to the United States who are also drawn to communities and ethnic enclaves on the basis of a shared mixed race ethnic heritage and social history.

\section{REFERENCES}

Alexander, Jeffrey C. 1990. "Analytic Debates: Understanding the Relative Autonomy of Culture" in Culture and Society Contemporary Debates. Editors, Jeffrey C. Alexander \& Steven Seidman. Cambridge: Cambridge University Press.

Billeaudeau, James. 1998. "Frilot Cove Community Exhibit" in The Natchitoches NSU Folk Festival Program" Creole Center Unprocessed Archive Records Natchitoches: Northwestern State University.

Clifford, James. 1997. Routes: Travel \& Translation in the Late Twentieth Century. Cambridge \& London: Harvard University 
Press.

Delphin, Terrel. 1995. The Creole Struggle and Resurrection: Our Story as Told by Creoles. Creole Center Unprocessed Archive Records Natchitoches: Northwestern State University.

Dominguez, Virginia. 1997. White By Definition: Social Classification in Creole Louisiana. New Brunswick, New Jersey, and London: Rutgers University Press.

Dormon, James H. 1996. "Ethnicity and Identity: Creoles of Color in Twentieth Century South Louisiana" in Creoles of Color of the Gulf South, edited by James H. Dormon. Knoxville: University of Tennessee Press.

Gehman, Mary. 1994. The Free People of Color of New Orleans. New Orleans: Margaret Media, Inc.

Keith, Michael. 2000. "Identity and the Spaces of Authenticity" in Theories of Race and Racism: A Reader. Editors, Les Back and John Solomos. London \& New York: Routledge.

Metoyer, Louis H. 2001. "Obituaries Section" in Bayou Talk Newspaper. Vol. 15 No. 3 Moreno Valley \& West Covina: JO VAL Inc Creole Center Unprocessed Archive Records Natchitoches: Northwestern State University.

Nagel, Joane. 1996. American Indian Ethnic Renewal: Red Power and the Resurgence of Identity and Culture. New York \& Oxford: Oxford University Press.

Nakashima, Cynthia. 1996. "Voices From the Movement: Approaches to Multiraciality" in The Multiracial Experience: Racial Borders as the New Frontier. Edited by Maria P. Root. Thousand Oaks: Sage Publications.

Parsons, Talcott. 1937. The Structure of Social Action. New York: McGraw Hill.

Ravare, Malinda. 1998. "Louisiana to California" in "The

Natchitoches NSU Folk Festival" Creole Center Unprocessed Archive Records Natchitoches: Northwestern State University.

Sarpy, John O. 2001. A Slave, A Frenchman, \& the Blood of a Saint. Shreveport: Sarpy Publishing.

Sewell, William H. 1999. "The Concept (s) of Culture" in Beyond the Cultural Turn: New Directions in the Study of Society and Culture. Edited by: Victoria E. Bonnell \& Lynn Hunt. Berkeley: 
University of California Press.

Singleton, Hubert D. 1999. The Indians Who Gave Us Zydeco: The Atakapas-Ishaks of Southwest Louisiana and Southeast

Texas. Hammond: HubertD.Singleton Publishing. CreoleCenter Unprocessed Archive Records Natchitoches: Northwestern State University.

Wall, Bennett H. 1984. Louisiana: A History. Arlington Heights, Illinois: The Forum Press, Inc.

Woods, Sr. Frances Jerome. 1972. Marginality and Identity: A Colored Creole Family Through Ten Generations. Baton Rouge: Louisiana State University Press.

Woods, Sr. Frances Jerome. 1989. Value Retention Among Young Creoles: Attitudes and Commitment of Contemporary Youth. Mellen Studies in Sociology, Vol. 5. Lewiston, New York: Edwin Mellen Press.

\section{FOOTNOTES}

${ }^{1}$ I would like to acknowledge the support of my dissertation chair, John Brown Childs at the University of California, Santa Cruz, Tomas Almaguer, my faculty mentor from San Francisco State University, Barbara Ustanko for her generous review and feedback on this paper, and the Ford Foundation Postdoctoral Fellowship Award Program which allowed me to secure important release time from my teaching duties to complete this research project which was in part based on research conducted for my dissertation at UC Santa Cruz in 2003.

2 The first sign of a change in the classification of Indians came in the form of a 1910 statute (act 220; Louisiana Revised Statute 9:201) that treated the union of an Indian and a person of the "colored and black" race as miscegenetic and thereby nullified it completely. Indians were thereby described as non-colored for the first time in Louisiana's legal history. 